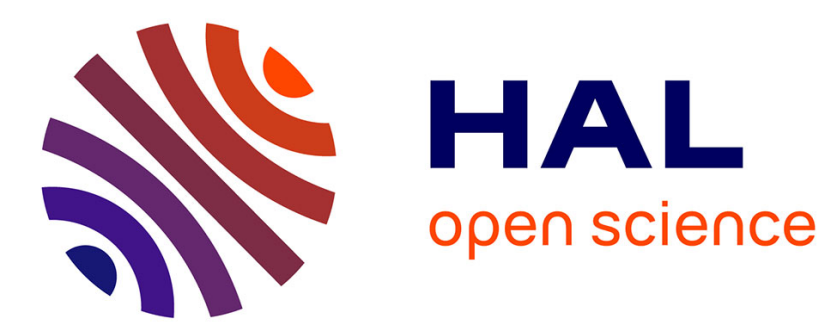

\title{
The Kinetics of Nickel Sorption on Pyrophyllite as Monitored by X-Ray Absorption Fine Structure (XAFS) Spectroscopy
}

\author{
A. Scheidegger, G. Lamble, D. Sparks
}

\section{- To cite this version:}

A. Scheidegger, G. Lamble, D. Sparks. The Kinetics of Nickel Sorption on Pyrophyllite as Monitored by X-Ray Absorption Fine Structure (XAFS) Spectroscopy. Journal de Physique IV Proceedings, 1997, 7 (C2), pp.C2-773-C2-775. 10.1051/jp4:1997233 . jpa-00255312

\section{HAL Id: jpa-00255312 https://hal.science/jpa-00255312}

Submitted on 1 Jan 1997

HAL is a multi-disciplinary open access archive for the deposit and dissemination of scientific research documents, whether they are published or not. The documents may come from teaching and research institutions in France or abroad, or from public or private research centers.
L'archive ouverte pluridisciplinaire HAL, est destinée au dépôt et à la diffusion de documents scientifiques de niveau recherche, publiés ou non, émanant des établissements d'enseignement et de recherche français ou étrangers, des laboratoires publics ou privés. 


\title{
The Kinetics of Nickel Sorption on Pyrophyllite as Monitored by X-Ray Absorption Fine Structure (XAFS) Spectroscopy
}

\author{
A.M. Scheidegger*, G.M. Lamble** and D.L. Sparks* \\ * Department of Plant and Soil Sciences, University of Delaware, Newark, DE 19717-1303, U.S.A \\ ** Bldg. 510E, Brookhaven National Laboratory, Upton, NY 11971, U.S.A
}

\begin{abstract}
A bstract: This study investigated the effect of reaction time (minutes to months) on the surface coordination environment of $\mathrm{Ni}$ sorbed onto pyrophyllite using XAFS. The data suggest the appearance of multinuclear $\mathrm{Ni}$ complexes after a reaction time of minutes. As reaction time progresses, these multinuclear Ni complexes increased in size $\left(\left(\mathrm{N}_{\mathrm{Ni}-\mathrm{Ni}}=1.4-4.5\right)\right.$. $\mathrm{Ni}-\mathrm{Ni}$ bond distances $(2.99-3.03 \AA)$ were similar to those for mixed $\mathrm{Ni}$-Al hydroxides $(3.03 \AA)$, but distinctively shorter than those for $\mathrm{Ni}(\mathrm{OH})_{2}(\mathrm{~s})(3.09 \AA)$. We propose that the formation of mixed $\mathrm{Ni}-\mathrm{Al}$ hydroxides may explain the observed bond distances and coordination numbers.
\end{abstract}

\section{INTRODUCTION}

Most studies on the kinetics of heavy metal sorption on clay and oxide surfaces reveal that sorption reactions are typically rapid initially, occurring on time scales of minutes or hours, then the rates diminish gradually, over time scales of days or weeks. The rapid stage is normally interpreted as an adsorption phenomenon [1]. There are several interpretations of the slow reaction stage: adsorption onto sites of lower reactivity [2], diffusion of the adsorbate into the adsorbent [3], and surface precipitation [4]. However, it is not possible to discriminate among the suggested sorption mechanisms without spectroscopic evidence.

The present study examines the kinetics and mechanisms of $\mathrm{Ni}(\mathrm{II})$ sorption on pyrophyllite at $\mathrm{pH}=7.5$. XAFS is used to monitor changes in the local atomic environment of sorbed Ni(II) and possible sorption modes are discussed. Pyrophyllite was selected because it shows little deviation from the ideal chemical formula $\left(\mathrm{Al}_{2} \mathrm{Si}_{4} \mathrm{O}_{10}(\mathrm{OH})_{2}\right)$ of $2: 1$ clays.

\section{EXPERIMENTAL PROCEDURE}

\subsection{Batch Studies}

The kinetics of $\mathrm{Ni}$ sorption on the $<2 \mu \mathrm{m}$ clay fraction of well characterized pyrophyllite at $\mathrm{pH}=7.5$ was studied following the procedure described elsewhere [5]. The initial Ni solution concentration ( $[\mathrm{Ni}]_{\text {initial }}=3 \mathrm{mM}$, ionic strength $\mathrm{I}=0.1 \mathrm{M}\left(\mathrm{NaNO}_{3}\right)$ ) was undersaturated with respect to the thermodynamic solubility product of $\mathrm{Ni}(\mathrm{OH})_{2}[5,6]$. In an effort to follow changes in the local atomic structure of the sorbed $\mathrm{Ni}$ ions as a function of reaction time $(15 \mathrm{~min}-24 \mathrm{~h})$, the experiment was conducted at the NSLS. By conducting kinetic studies at the NSLS, XAFS samples could be immediately measured and any possible impact of the storage time on the metal coordination environment prior to the analyses could be avoided. Collected samples were passed through a $0.22 \mu \mathrm{m}$ membrane filter and the remaining wet pastes were immediately washed with excess high-purity water to adequately remove entrained electrolyte and non sorbed $\mathrm{Ni}$, and then filtered again. The washing process was repeated twice. Previous results have demonstrated that the washing process does not result in significant Ni desorption [5]. The wet pastes were then mounted on a sample holder for XAFS analysis.

\subsection{XAFS Studies}

XAFS spectra were recorded at beamline X-11A at the NSLS. A Si (111) crystal was employed in the monochromator. Beam energy was calibrated by assigning the first inflection on the $\mathrm{K}$ absorption edge of a nickel metal foil to an energy of $8333 \mathrm{eV}$. The spectra were collected in fluorescence mode at $77 \mathrm{~K}$ to reduce dampening of the XAFS oscillation by thermal disorder and to eliminate any possibility of a further reaction. Data analysis was accomplished using the program EXCURVE [7]. Amplitude parameters and phase shifts for $\mathrm{Ni}, \mathrm{O}$ and $\mathrm{Si} / \mathrm{Al}$ were obtained experimentally from the spectra of crystalline $\mathrm{Ni}(\mathrm{OH})_{2}$ and $\mathrm{Ni}_{2}$ Si. Details on the data analysis are presented elsewhere [5].

\section{RESULTS AND DISCUSSION}

Ni sorption on pyrophyllite at $\mathrm{pH}=7.5$ resulted in the presence of multinuclear Ni complexes within minutes. This can be clearly demonstrated in Figure 1 . There is a small peak at $R \approx 2.8 \AA$ in the radial structure function (RSF) of pyrophyllite treated with $\mathrm{Ni}$ for 15 minutes (Figure 1f). This peak represents the second $\mathrm{Ni}$ shell and reflects backscattering among multinuclear $\mathrm{Ni}$ complexes. The presence of multinuclear Ni complexes after a sorption time of only 15 minutes (28\% of the initial $\mathrm{Ni}$ sorbed; Table I) is a rather surprising finding. Traditionally, adsorption (strictly a two-dimensional process) is considered to be the predominant sorption mode responsible for metal uptake on mineral surfaces within the first few hours [1]. 


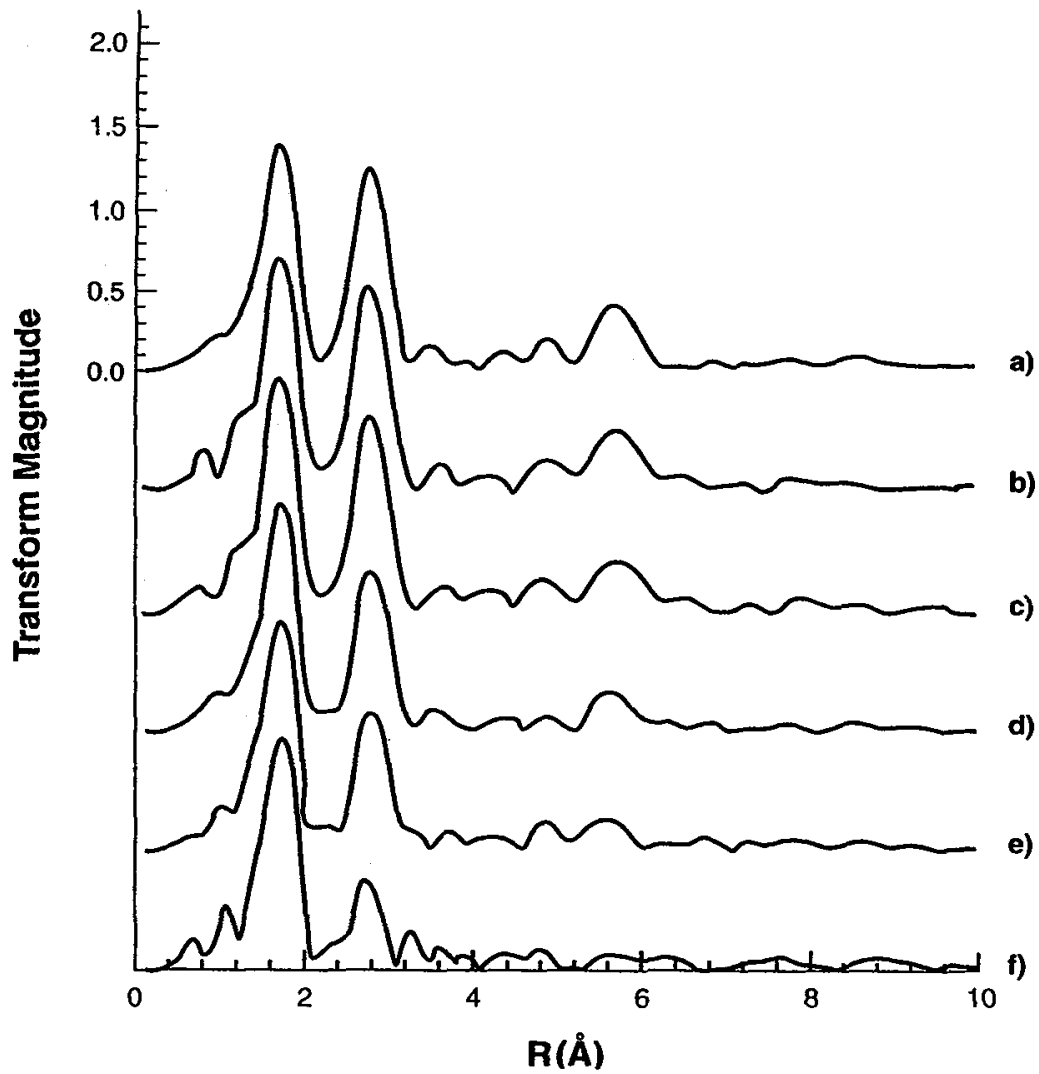

Figure 1: Radial structure functions (RSFs) of pyrophyllite samples reacted with Ni for a) 3 months, b) $24 \mathrm{~h}$, c) $12 \mathrm{~h}$, d) $3 \mathrm{~h}$, e) $75 \mathrm{~min}$, and f) $15 \mathrm{~min}$. The spectra are uncorrected for phase shift. Note the appearance of a peak at a $R$ of about $2.8 \AA$ with increasing reaction time.

Table I: Structural information derived from XAFS analysis using EXCURVE [7]: Interatomic distances (R, $\AA$ ), Coordination numbers $(\mathrm{N})$, and Debye-Waller factors $\left(2 \sigma^{2}, \AA^{2}\right)$. The reported values are accurate to within $\mathrm{R} \pm 0.02 \AA, \mathrm{N}_{(\mathrm{Ni}-\mathrm{O})} \pm 20 \%, \mathrm{~N}_{(\mathrm{Ni}-\mathrm{Ni})} \pm 20 \%, \mathrm{~N}_{(\mathrm{Ni}-\mathrm{Si} / \mathrm{Al})}$ $\pm 40 \%$.

\begin{tabular}{|c|c|c|c|c|c|c|c|c|c|c|c|}
\hline & & & \multicolumn{3}{|c|}{$\mathrm{Ni}-\mathrm{O}$} & \multicolumn{3}{|c|}{$\mathrm{Ni}-\mathrm{Ni}$} & \multicolumn{3}{|c|}{$\mathrm{Ni}-\mathrm{Si} / \mathrm{Al}$} \\
\hline $\begin{array}{l}\text { reaction } \\
\text { time }\end{array}$ & $\begin{array}{l}\text { rel. } \mathrm{Ni} \\
\text { removal } \\
{[\%]} \\
\end{array}$ & $\begin{array}{l}\text { sorption } \\
\text { density } \Gamma \\
\mu \mathrm{mol} / \mathrm{m}^{2}\end{array}$ & $\begin{array}{l}\mathbf{R} \\
(\dot{A})\end{array}$ & $\mathrm{N}$ & $2 \sigma^{2}$ & $\begin{array}{l}\mathbf{R} \\
(\AA)\end{array}$ & $\mathbf{N}$ & $2 \sigma^{2}$ & $\begin{array}{l}R \\
(\AA)\end{array}$ & $\mathrm{N}$ & $2 \sigma^{2}$ \\
\hline $15 \mathrm{~min}$ & 28 & 0.7 & 2.03 & 6.0 & 0.009 & 2.99 & 1.4 & 0.007 & 2.96 & 1.5 & 0.004 \\
\hline $75 \mathrm{~min}$ & 44 & 1.1 & 2.03 & 6.4 & 0.01 & 3.01 & 3.1 & 0.009 & 3.04 & 1.6 & 0.01 \\
\hline $3 \mathrm{~h}$ & 67 & 1.7 & 2.02 & 6.2 & 0.009 & 3.03 & 3.4 & 0.01 & 3.07 & 1.6 & 0.011 \\
\hline $12 \mathrm{~h}$ & 93 & 2.4 & 2.03 & 6.4 & 0.01 & 3.02 & 4.1 & 0.009 & 3.07 & 2.1 & 0.009 \\
\hline $24 \mathrm{~h}$ & 97 & 2.6 & 2.03 & 6.5 & 0.01 & 3.02 & 4.2 & 0.01 & 3.07 & 1.8 & 0.013 \\
\hline 3 months & & 3.1 & 2.03 & 6.5 & 0.01 & 3.02 & 4.5 & 0.011 & 3.07 & 2.4 & 0.016 \\
\hline
\end{tabular}


As reaction time progressed ( $15 \mathrm{~min}$ to $24 \mathrm{~h}$ ) and relative $\mathrm{Ni}$ removal in solution increased from $28 \%$ to $97 \%$ (Table $\mathrm{I}$ ) the peak at $\mathrm{R} \approx 2.8 \AA$ in the RSFs increased in intensity (Fig. 1b, c, d, and e). For comparison we measured also a sample which had been treated with Ni under similar conditions for 3 months (Table I). The same features can be detected in the RSF (Fig. 1a).

XAFS analysis suggested that in the first coordination shell $\mathrm{Ni}$ is surrounded by $6 \mathrm{O}$ atoms (Table I). This behavior indicated that $\mathrm{Ni}(\mathrm{II})$ is in an octahedral environment. The $\mathrm{Ni}-\mathrm{O}$ bond distance $(2.03 \AA)$ and coordination numbers were not affected by the reaction time. For the second shell best fits were obtained by incorporating $\mathrm{Ni}$ and $\mathrm{Si}$ or $\mathrm{Al}$ as second-neighbor backscatterer atoms [8]. Table I. reveals that as the reaction time increased from 15 minutes to 3 months, the number of Ni second-neighbor $(N)$ atoms at a distance of 2.99-3.03 $\AA$ increased from $N=1.4-4.5$. This finding suggests the formation of multinuclear $\mathrm{Ni}$ complexes increasing in size with progressing reaction time.

We observe the onset of multinuclear $\mathrm{Ni}$ complex formation at a surface loading as low as $0.7 \mu \mathrm{mol} \mathrm{m} \mathrm{m}^{-2}$. If the closestpacking of $\mathrm{NiO}_{6}$ polyhedra is assumed to constitute a monolayer of $\mathrm{Ni}$ atoms, $\Gamma=0.75 \mu \mathrm{mol} \mathrm{m}^{-2}$ corresponds to $<10 \%$ of monolayer coverage [5].

We propose that the formation of mixed $\mathrm{Ni}-\mathrm{Al}$ hydroxides may explain the observed bond distances and coordination numbers. In a recent study, spectroscopic evidence for the formation of mixed $\mathrm{Ni}$-Al hydroxides upon Ni sorption on clay and aluminum oxides was presented [8]. Indeed, $\mathrm{Ni}-\mathrm{Ni}$ bond distances in the present study (3.0-3.03 $\AA$; Table I) correspond well with those found in mixed Ni-Al hydroxides (3.03-3.05 $\AA$ ) [8,9], but are distinctively shorter than those in $\mathrm{Ni}(\mathrm{OH})_{2}(\mathrm{~s})(3.09 \AA)$ $[5,8]$. Aluminum could have been released into solution and incorporated into mixed (Al, Ni) hydroxides. Indeed, macroscopic data suggest that the dissolution of pyrophyllite is enhanced during reaction with Ni relative to the dissolution in the bulk solution [5].

\section{Acknowledgment}

We gratefully acknowledge the support of this research by the DuPont Company. This work was performed at beamline X-11A at the NSLS, which is supported by the US DOE office of Basic Energy Sciences under contract numbers DE-ACO276CH00016 and DE-AS05-80-ER10742.

\section{References:}

[1] Sparks, D. L., Environmental soil chemistry (Academic Press, San Diego. 1995) pp. 99-139.

[2] Dzombak, D. A. and Morel, F. M. M. ; J. Colloid Interface Sci. 112 (1986) 588-598.

[3] Brümmer, G. W., Gerth, J. and Tiller, K. G.; Soil Sci. 39 (1988) 37-52.

[4] Davis, J. A., Fuller, C. C., and Cook, A. D. ; Geochim. Cosmochim. Acta 51 (1987) 1477-1490.

[5] Scheidegger, A. M., Lamble, G. M. and Sparks, D. L. ; Environ. Sci. Technol. 30 (1996) 548-554.

[6] Scheidegger, A. M., Fendorf, M. and Sparks, D. L. ; Soil. Sci. Soc. Am. J., 60 (1996) 1763-1772.

[7] Gurman, S. J., Binsted, N. and Ross, I. ; J. Physics C 19 (1986) 1845-1861.

[8] Scheidegger, A. M., Lamble, G. M. and Sparks, D. L. ; J. Colloid Interface Sci. 186 (1997) 118-128.

[9] Bish, D. L. and Brindley, G. W. ; Am. Mineral. 62 (1977) 458-464. 